\title{
Increased renal gene transcription of protein kinase $C-\beta$ in human diabetic nephropathy: relationship to long-term glycaemic control
}

\author{
R. G. Langham • D. J. Kelly • R. M. Gow • Y. Zhang • \\ A. J. Cox $\cdot$ W. Qi $\cdot$ K. Thai $\cdot$ C. A. Pollock • \\ P. K. Christensen • H.-H. Parving • R. E. Gilbert
}

Received: 2 April 2007 / Accepted: 11 December 2007 / Published online: 16 February 2008

(C) Springer-Verlag 2008

\begin{abstract}
Aims/hypothesis Activation of protein kinase C (PKC) isoforms has been implicated as a central mediator in the pathogenesis of diabetic nephropathy. Although high glucose levels stimulate catalytic activity of PKC, the effects of high glucose levels on the expression of genes encoding PKC isoforms are unknown. We sought to determine whether in addition to activation, diabetes may lead to increased transcription of two PKC isoforms that have been implicated in the pathogenesis of diabetic nephropathy, PKC- $\alpha$ and PKC- $\beta$.
\end{abstract}

R. G. Langham • D. J. Kelly $\cdot$ R. M. Gow $\cdot$ Y. Zhang $\cdot$ A. J. Cox $•$

W. Qi $\cdot$ R. E. Gilbert

University of Melbourne Department of Medicine,

St Vincent's Hospital,

Fitzroy, VIC, Australia

R. G. Langham $(\square)$

Department of Nephrology, St Vincent's Hospital,

41 Victoria Parade,

Fitzroy, VIC 3065, Australia

e-mail: rlangham@medstv.unimelb.edu.au

K. Thai $\cdot$ R. E. Gilbert

Keenan Research Centre in the Li Ka Shing Knowledge Institute,

St Michael's Hospital Department of Medicine,

University of Toronto,

Toronto, ON, Canada

C. A. Pollock

University of Sydney Department of Medicine,

Royal North Shore Hospital,

Sydney, NSW, Australia

P. K. Christensen • H.-H. Parving

Department of Medical Endocrinology,

University Hospital of Copenhagen,

Copenhagen, Denmark
Methods Recent advances in molecular biological techniques now permit quantitative analysis of mRNA from archival, formalin-fixed, paraffin-embedded tissue sections. RNA was extracted from scraped $6 \mu \mathrm{m}$ sections of biopsy tissue, and PRKC- $\alpha$ and PRKC- $\beta$ (also known as PRKCA and $P R K C B)$ mRNA measured using real-time PCR. Expression of genes encoding PKC isoforms was examined in renal biopsies $(n=25)$ with classical histological features of diabetic nephropathy and compared with that in normal control tissue $(n=6)$. Peptide localisation of PKC- $\alpha$, PKC- $\beta$ and the activated forms phosphorylated PKC- $\alpha$ and $-\beta$ was also performed on matched paraffin-embedded sections of renal biopsies using immunohistochemistry. The effects of high glucose on PRKC- $\beta$ expression and peptide production in cultured human proximal tubular epithelial cells were assessed.

Results Quantitative real-time PCR demonstrated a 9.9-fold increase in PRKC- $\beta$ mRNA in kidney biopsies of diabetic patients relative to control $(p<0.001)$. No increase in $P R K C$ $\alpha$ expression was seen. In addition, a correlation between renal $P R K C-\beta$ mRNA and $\mathrm{HbA}_{1 \mathrm{c}}$ was observed in diabetic patients $(r=0.63, p<0.05)$. There was co-localisation of PKC- $\beta$ and phospho-PKC- $\beta$ predominantly to proximal tubules. A $60 \%$ increase in PRKC- $\beta$ mRNA and peptide in cultured human proximal tubular epithelial cells exposed to high glucose $(p<0.05)$ was seen in vitro.

Conclusions/interpretation PKC- $\beta$ is upregulated at the gene expression level in human diabetic nephropathy. PRKC- $\beta$ mRNA correlates closely with serum $\mathrm{HbA}_{1 \mathrm{c}}$, possibly partially explaining the relationship between glycaemic control and progression of diabetic nephropathy. Archival human tissue provides a valuable resource for molecular analyses. 
Keywords Diabetic nephropathy · Human renal biopsies . Hyperglycaemia $\cdot$ PKC- $\alpha \cdot$ PKC- $\beta \cdot$ Protein kinase C · RT-PCR

\section{Abbreviations \\ DAG diacylglycerol \\ PKC protein kinase $\mathrm{C}$ \\ PTC proximal tubular cells \\ $C_{\mathrm{t}} \quad$ cycle threshold}

\section{Introduction}

Diabetic nephropathy is a leading cause of end-stage kidney disease throughout much of the world [1]. Hyperglycaemia, a central prerequisite of diabetic nephropathy, correlates with both the development [2] and progression of the disease [3]. Over the past two decades a number of glucosedependent pathways have been implicated in the pathogenesis of diabetic kidney disease [4]; these include activation of protein kinase $\mathrm{C}$ (PKC) [5], with both experimental and clinical studies highlighting the importance of the beta isoform $[6,7]$. The alpha isoform has also been implicated in the pathogenesis of diabetic nephropathy, potentially mediating changes that lead to albuminuria in the diabetic glomerulus $[8,9]$.

Binding of diacylglycerol (DAG) to the inactive forms of both the classical and novel PKC isoforms plays an important role in inducing activation of PKC [10]. Indeed traditionally, the increased activity of PKC in the diabetic state has been attributed to enhanced production of DAG as a consequence of increased flux through the glycolytic and pentose phosphate pathways [11]. However, in addition to allosteric modification, a number of in vitro studies have shown that high glucose levels not only change PKC activity, but also increase PKC protein $[12,13]$. Increases in PKC- $\beta$ protein levels have also been demonstrated in the in vivo context in rodent models of diabetic nephropathy [14], with more recent studies also showing increased $P R K C-\beta$ (also known as $P R K C B$ ) expression [15]. In this study, we sought to determine the role of $P R K C-\beta$ transcription in the subsequent amplified activation that has been demonstrated in several models of diabetic nephropathy.

While the glomerulus, and in particular the mesangium, has been the focus of intense investigation in diabetes, tubulointerstitial injury is also a major feature of diabetic nephropathy and an important predictor of renal dysfunction [16]. Accordingly, we sought to determine the effects of high glucose on PRKC- $\alpha$ (also known as PRKCA) and PRKC- $\beta$ expression in tubular epithelial cells and to examine the magnitude of expression and site-specific localisation of the two isoforms in human diabetic nephropathy in relation to glycaemic control.

\section{Methods}

In vitro study

The methods for primary culture of human proximal tubular cells (PTC) are described elsewhere [17]. In brief, segments of macroscopically normal renal cortex were obtained under aseptic conditions from patients undergoing nephrectomy for small $(<6 \mathrm{~cm})$ tumours. Patients were accepted for inclusion into the study if there was no history of renal or systemic disease known to be associated with tubulointerstitial pathology. In addition, the presence of a histologically normal cortical tubulointerstitium at sites removed from the tumour was confirmed by independent pathological examination. Written informed consent was obtained from each patient prior to surgery and ethical approval for the study was obtained from the Royal North Shore Hospital Human Research Ethics Committee. The current study assayed the $P R K C-\alpha$ and PRKC- $\beta$ transcription response to a highglucose environment in PTCs from three separate patients.

PTCs were seeded at 15,000 per well in 96-well culture dishes in hormonally defined media. When $50 \%$ confluence had been reached, cells were quiesced for $24 \mathrm{~h}$ in basal medium consisting of DMEM and Hams F-12 (1:1, vol./vol.; ThermoTrace, Noble Park, VIC, Australia), supplemented with $5 \mu \mathrm{g} / \mathrm{ml}$ human transferrin (Sigma Chemicals, St Louis, MO, USA), penicillin $(100 \mathrm{U} / \mathrm{ml})$ and streptomycin $(100 \mu \mathrm{g} / \mathrm{ml}$; Gibco BRL, Gaithersburg, MD, USA). The cells were then cultured for $48 \mathrm{~h}$ in basal medium containing $5 \mathrm{mmol} / \mathrm{l}$ glucose and $30 \mathrm{mmol} / \mathrm{l}$ glucose, each done in triplicate.

To quantify $P R K C-\alpha$ and $-\beta$ transcription, RNA was extracted and $P R K C-\alpha$ and $-\beta$ mRNA measured with PCR as described below.

\section{Biopsy study}

Renal tissue was obtained from biopsy samples stored from a study in which histology and clinical data have been previously reported [18]. In brief, 49 patients with type 2 diabetes and evidence of proteinuria but no retinopathy underwent percutaneous needle biopsy of the kidney to assess renal histology. Of the entire cohort, 69\% (34) of the patients had evidence of diabetic nephropathy in their biopsy, the remainder had either normal glomerular (nine) structure or glomerulonephritis (six). Of the diabetic nephropathy cohort, 25 archival biopsies contained sufficient biopsy material for molecular analysis. Relevant clinical data were also analysed.

RNA extraction and cDNA synthesis

RNA was extracted from paraffin-embedded blocks of study tissue by cutting a $6 \mu \mathrm{m}$ section and placing it into 
$200 \mu \mathrm{l}$ RNA lysis buffer. Next, $200 \mu 1$ water-saturated phenol and chloroform was added to the RNA sample, which was mixed well and centrifuged for $2 \mathrm{~min}$ at $4^{\circ} \mathrm{C}(16,000 \mathrm{~g})$. Following removal of the supernatant fractions, the phenolchloroform extraction was repeated and followed by a further chloroform extraction. Samples were then precipitated with $180 \mu \mathrm{l}$ isopropanol, $18 \mu \mathrm{l} 3 \mathrm{~mol} / \mathrm{l}$ sodium acetate (pH 5.2) and $1 \mu \mathrm{l}$ carrier glycogen $(20 \mathrm{mg} / \mathrm{ml})$ at $20^{\circ} \mathrm{C}$. After centrifuging for $15 \mathrm{~min}$ at $4^{\circ} \mathrm{C}(16,000 \mathrm{~g})$, the supernatant fraction was discarded and the RNA pellet was washed with $1 \mathrm{ml}$ cold $70 \%$ diethyl pyrocarbonate-treated ethanol, centrifuged for $10 \mathrm{~min}$ at $4^{\circ} \mathrm{C}(16,000 \mathrm{~g})$ and resuspended in $10 \mu \mathrm{l}$ RNase-free diethyl pyrocarbonate water.

Of RNA extracted from tissue sections, $1 \mu \mathrm{l}$ was reversetranscribed in a final volume of $20 \mu$ using M-MLV reverse transcriptase (Gibco-BRL, Carlsbad, CA, USA) in the manufacturer's buffer containing $1 \mathrm{mmol} / 1 \mathrm{dNTPs}, 40 \mathrm{U}$ RNase inhibitor (Amersham Pharmacia Biotech, Freiburg, Germany), 300 ng random hexamers (Pharmacia) and $7 \mu 1$ RNA. The reactions took place at $42^{\circ} \mathrm{C}$ for $60 \mathrm{~min}$, followed by $95^{\circ} \mathrm{C}$ for $5 \mathrm{~min}$ and $4^{\circ} \mathrm{C}$ for $5 \mathrm{~min}$.

\section{Real-time PCR}

PRKC- $\alpha$ and PRKC- $\beta$ expression was measured and quantified using the a sequence detector (GeneAmp 5700; PE Biosystems, Foster City, CA, USA) according to the manufacturer's instructions. Primers were obtained from Sigma-Aldrich. Sequences of primer and probe are as follows: (1) PRKC- $\alpha$; commercial PCR probe and primers (Gene Expression Assay; Applied Biosystems, Foster City, CA, USA), assay ID Hs00176973_m1; (2) PRKC- $\beta$ forward primer CTTCAAGCAGCCCACCTTCT, reverse primer TCCCCGAAGCCCCAGATG, probe AGCCACTGCACC GAC. The fluorogenic probe (Applied Biosystems) includes a fluorescence reporter (6-carboxyfluorescein) at the $5^{\prime}$-end and a fluorescent quencher (6-carboxytetramethylrhodamine [TAMRA]) at the 3 '-end. A commercial, pre-developed $18 \mathrm{~S}$ control kit labelled with VIC, a fluorescent reporter dye on the $5^{\prime}$-end and the quencher (TAMRA) on the $3^{\prime}$-end (PE Biosystems) was used as the endogenous control. Similar amplification efficiencies of $P R K C-\alpha, P R K C-\beta$ and $18 \mathrm{~S}$ were validated, permitting semi-quantitative measurement of gene expression.

The $25 \mu \mathrm{l}$ PCR mixture contained $12.5 \mu$ l Taqman Universal PCR Master Mix (Applied Biosystems), $500 \mathrm{nmol} / 1$ primers (forward and reverse), $100 \mathrm{nmol} / 1$ Taqman probe and $1 \mu \mathrm{l}$ of cDNA template. PCR was performed at $50^{\circ} \mathrm{C}$ for $2 \mathrm{~min}, 95^{\circ} \mathrm{C}$ for $10 \mathrm{~min}$ and then run for 50 cycles at $95^{\circ} \mathrm{C}$ for $15 \mathrm{~s}$ and $60^{\circ} \mathrm{C}$ for $1 \mathrm{~min}$. Comparative cycle threshold $\left(C_{\mathrm{t}}\right)$ calculations were all relative to the control group. $18 \mathrm{~S} C_{\mathrm{t}}$ values were subtracted from $P R K C C_{\mathrm{t}}$ values to give a $\Delta C_{\mathrm{t}}$ value. $\Delta \Delta C_{\mathrm{t}}$ values were achieved by subtracting the average control $\Delta C_{\mathrm{t}}$ value, for each animal group. Expression of the genes encoding PKC isoforms relative to control was derived using the equation $2^{-\Delta \Delta C_{\mathrm{t}}}$.

PKC- $\beta$ localisation and activation

PKC- $\beta 1$ and $-\beta 2$ peptides and their phosphorylated isoforms (phospho-PKC- $\beta 1$ and $-\beta 2$ ) were localised by immunostaining using polyclonal rabbit anti-PKC- $\beta 1$ and $-\beta 2$ antibodies (Santa Cruz Biotechnology, Santa Cruz, CA, USA) and polyclonal rabbit anti-phospho-PKC- $\beta 1$ and $-\beta 2$ antibodies (Biosource International, Camarillo, CA, USA).

Tissue sections (4 $\mu \mathrm{m}$ thick) were prepared from paraffin-embedded tissue of study biopsies and immunostained as previously described [19] according to the manufacturer's instructions. Sections incubated with 1:10 normal goat serum, instead of the primary antiserum served as the negative control. Sequential sections were obtained to determine co-localisation of PKC- $\beta 1$, PKC- $\beta 2$ and phospho-PKC- $\beta 1$ and- $\beta 2$.

Western blot analysis

PKC- $\beta$ activation was measured by western blot analysis of phosphorylated PKC- $\beta$ peptide normalised to actin (Labvision, Fremont, CA, USA) using a method already described [12].

\section{Results}

In vitro study

After $48 \mathrm{~h}$, exposure of human proximal tubular epithelial cells exposed to $30 \mathrm{mmol} / 1$ glucose led to a $65 \%$ increase in PRKC- $\beta$ mRNA compared with cells grown in a $5 \mathrm{mmol} / \mathrm{l}$ glucose environment (Fig. 1a). Western blot measuring the amount of phosphorylated PKC- $\beta$ demonstrated a discernible increase in phospho-PKC- $\beta$ in PTCs exposed to a high-glucose environment for $48 \mathrm{~h}$ compared with those exposed to low glucose (Fig. 1b).

Human biopsy study

Clinical data Of the 34 biopsies from the previously reported study, 25 contained sufficient tissue to extract suitable quantities of RNA. This subset of patients displayed the characteristic features of diabetic nephropathy with proteinuria, hypertension in all but one, declining glomerular filtration rate, glomerulosclerosis and tubulointerstitial fibrosis (Table 1).

PRKC- $\beta$ and PRKC- $\alpha$ expression Analysis of PRKC- $\beta$ expression in the diabetic biopsies demonstrated a near 


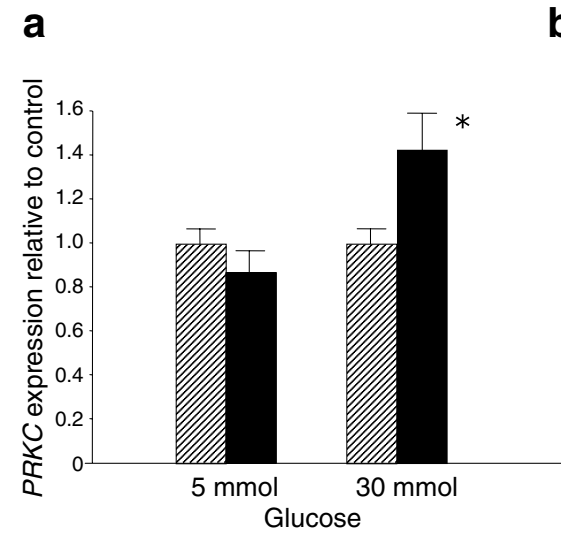

Fig. 1 a Effects of high glucose environment on $P R K C-\alpha$ (hatched bars) and $P R K C-\beta$ (black bars) expression of cultured human PTC, demonstrating a $50 \%$ increase in $P R K C-\beta$ in high glucose medium, but no discernible change with $P R K C-\alpha$. Values are mean \pm SEM; ${ }^{*} p<0.05$.

tenfold increase in specific mRNA when compared with control tissue (Fig. 2). A close correlation $(r=0.63)$ was noted (Fig. 3) between PRKC- $\beta$ expression and $\mathrm{HbA}_{1 \mathrm{c}}$ at the time of biopsy, but not with any of the other clinical or structural indices documented in the study. As only one patient was classified as not hypertensive, the role of hypertension in the gene transcription of $P R K C-\beta$ could not be determined. There was no detectable increase in PRKC$\alpha$ gene expression in the biopsy samples.

$P K C-\beta$ localisation Immunolocalisation of PKC- $\beta 1$ and PKC- $\beta 2$ peptide revealed a predominant tubulo-epithelial pattern of increased abundance in the diabetic biopsies, with only sparse glomerular staining (Fig. 4). In serial sections, colocalisation of PKC- $\beta 1$ and PKC- $\beta 2$ was noted. Furthermore, immunostaining for phosphorylated PKC- $\beta 1$ and PKC- $\beta 2$ as a measure of PKC- $\beta$ tissue activation confirmed co-localisation with PKC- $\beta 1$ and $-\beta 2$ (Fig. 4).

\section{Discussion}

Intensive investigation over several decades has implicated excessive activity of four glucose-dependent pathways in
C

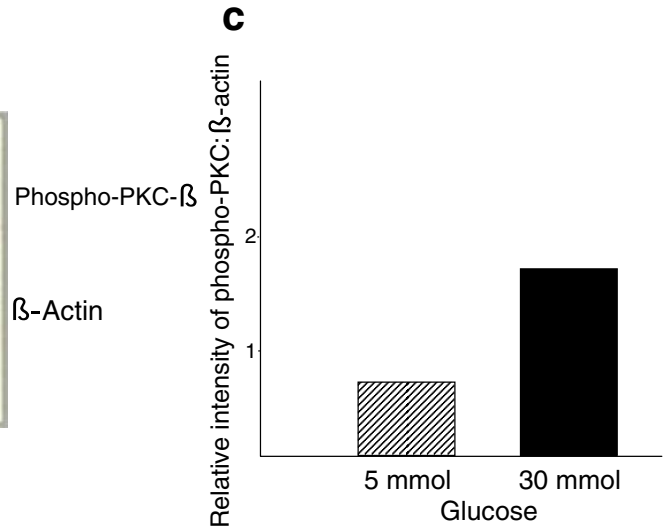

b Western blot analysis and (c) quantification of phosphorylated PKC- $\beta$ in protein lysates from cultured human proximal tubules exposed to high $(30 \mathrm{mmol} / \mathrm{l})$ and low $(5 \mathrm{mmol} / \mathrm{l})$ glucose

the pathogenesis of the long-term complications of diabetes: the polyol pathway, advanced glycation end-product formation, hexosamine flux and activation of PKC [4]. The pathogenetic role of PKCs and the $\beta$-isoform, in particular, in diabetic complications has traditionally been attributed to high intracellular glucose inducing de novo synthesis of DAG, leading to enzyme activation by allosteric modification $[4,5]$. However, observations by Kapor-Drezgic et al. [12] several years ago showed that in addition to activating the enzyme, high glucose also induced an increase in PKC$\beta$ protein (and also $\alpha$ and $\varepsilon$ ) after exposing mesangial cells to high glucose for $48 \mathrm{~h}$, but not after $12 \mathrm{~h}$ of exposure. Consistent with this, Kelly et al. [14] reported increased PKC- $\beta$ protein in the kidneys of diabetic rats and that this increase was attenuated by inhibiting enzyme activity with the PKC- $\beta$ inhibitor, ruboxistaurin. While not readily explainable at the time, more recent studies have shown that PKC- $\beta$ regulates its own expression in vivo, requiring the presence of the active form of the enzyme for modulation of its transcription [20]. In the present study, using archival biopsy tissue from a previously reported study, we documented an increase in PRKC- $\beta$ mRNA, but not $P R K C-\alpha$ mRNA, in kidney biopsies from diabetic patients, showing a close correlation with glycaemic

Table 1 Clinical data collected at the time of biopsy

Data are expressed as mean \pm SEM, with the exception of albuminuria, which is expressed as geometric mean (95th centile $\mathrm{CI}$ ) N/A, not applicable

\begin{tabular}{lll}
\hline & Diabetic nephropathy $(n=33)$ & Control $(n=6)$ \\
\hline Age (years) & $55 \pm 1.4$ & $56 \pm 9$ \\
Sex (male/female) & $26 / 7$ & $4 / 2$ \\
$\mathrm{HbA}_{1 \mathrm{C}}(\%)$ & $8.3 \pm 0.3$ & $\mathrm{~N} / \mathrm{A}$ \\
Duration of diabetes (years) & $6.7 \pm 1.0$ & $\mathrm{~N} / \mathrm{A}$ \\
Creatinine clearance (ml/min) & $97 \pm 5$ & $103 \pm 4$ \\
Mean systolic BP (mmHg) & $150 \pm 2.9$ & $137 \pm 3.2$ \\
Mean diastolic BP (mmHg) & $87 \pm 1.5$ & $82 \pm 4$ \\
Glomerulosclerosis index & $2.1 \pm 0.2$ & $0.3 \pm 0.01$ \\
Albuminuria (mg/day) & $1,420(253-4,830)$ & $\mathrm{N} / \mathrm{A}$ \\
\hline
\end{tabular}




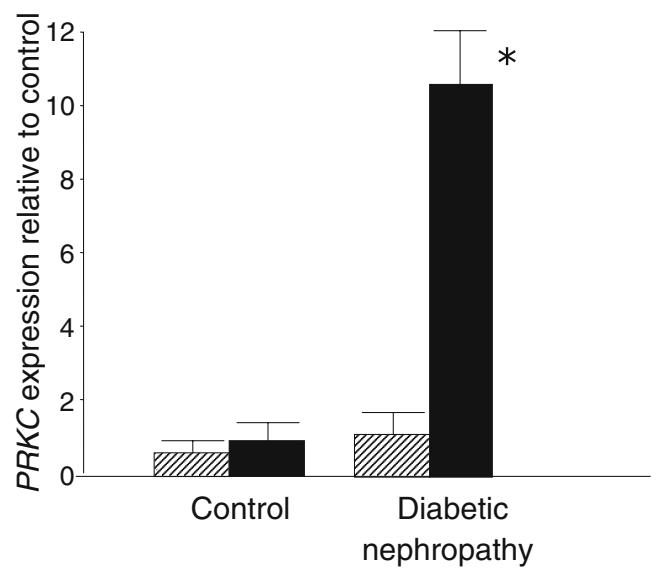

Fig. 2 RT-PCR measurement of $P R K C-\alpha$ (hatched bars) and $P R K C-\beta$ (black bars) expression in archival human kidney tissue, demonstrating a tenfold increase in $P R K C-\beta$ in diabetic nephropathy samples and no significant change in $P R K C-\alpha$ mRNA. Mean \pm SEM of six (control) and 33 (diabetic nephropathy) samples; ${ }^{*} p<0.001$

exposure. Moreover, when renal tubular epithelial cells, the major source of PKC- $\beta$ protein in our tissues with advanced diabetic nephropathy, were exposed to $30 \mu \mathrm{mmol} / 1$ glucose for $48 \mathrm{~h}, P R K C-\beta$ mRNA increased, with evidence of phosphorylation following analysis of cell culture peptide fraction. The present study demonstrates that in addition to the already identified role of high glucose in the allosteric modification and activation of PKC isoforms, modulation of $P R K C-\beta$ expression by high glucose may further increase the amount of peptide production that is then available for activation, thus compounding the contribution of high glucose to the pathogenesis of diabetic nephropathy and possibly of other long-term complications of diabetes.

In the present study, performed using biopsies from patients with advanced diabetic nephropathy, PKC- $\beta$ was localised predominantly to tubular epithelial cells. These findings are consistent with the recent findings of Toyoda et al. [15], who reported an increase in glomerular PRKC- $\beta$ mRNA in early diabetic nephropathy, but not in patients with advanced disease. In our study of patients with relatively advanced disease, we also did not find increased glomerular $P K C-\beta$ expression by immunohistochemistry. However, we did note abundant PKC- $\beta$ protein in tubular epithelial cells, consistent with the tenfold increase in PRKC- $\beta$ mRNA noted by quantitative PCR analysis. Together these findings suggest that while production of PKC- $\beta$ is predominantly glomerular in early diabetic nephropathy, advanced disease is characterised by predominantly tubular production.

Several observational and interventional studies have documented the close relationship between average glycaemic control over several years and both the development and progression of diabetic nephropathy $[2,3]$. In the present study we found a significant correlation between PRKC- $\beta$ mRNA and $\mathrm{HbA}_{1 \mathrm{c}}$ at the time of biopsy. However, no relationship between $P R K C-\beta$ mRNA and a range of other clinical or histopathological indices of injury was noted. While these findings raise the possibility that PKC- $\beta$ levels may be a marker of glucose exposure rather than a pathogenetic factor in diabetic nephropathy, this seems unlikely given the ability of the PKC- $\beta$ inhibitor, ruboxistaurin, to attenuate the disordered structure and function, not only in experimental diabetic nephropathy [7], but also in the human context. We speculate that the lack of correlation between $P R K C-\beta$ mRNA and renal structure or function may be related to the chronology of disease. While $\mathrm{HbA}_{1 \mathrm{c}}$ reflects average glycaemia over the preceding 8 to 12 weeks and alterations in gene expression typically occur over a few hours or days, changes in kidney structure and function take years to develop [21]. There are other potential mechanisms that may promote $P R K C-\beta$ gene transcription. Our own preliminary studies have demonstrated a smaller but no less significant increase in gene expression of $P R K C-\beta$ in biopsies from progressive IgAN (IgA nephropathy) [22].

In combination with clinical data, formalin-fixed, paraffin-embedded tissue provides an important resource for determining structure-function relationships in a range of human diseases. Formalin fixation, however, causes crosslinks between RNA and protein, as well as the addition of mono-methylol groups to RNA bases and methylene bridging of adenine groups and fragmentation [23]. These changes in RNA structure have, until recently, limited not only the amount of RNA that can be extracted from archival tissue, but also its quantitative analysis. However, technological advances now allow for successful RNA extraction from formalin-fixed tissues by elevating the buffer temperature and by prolonged proteinase $\mathrm{K}$ digestion

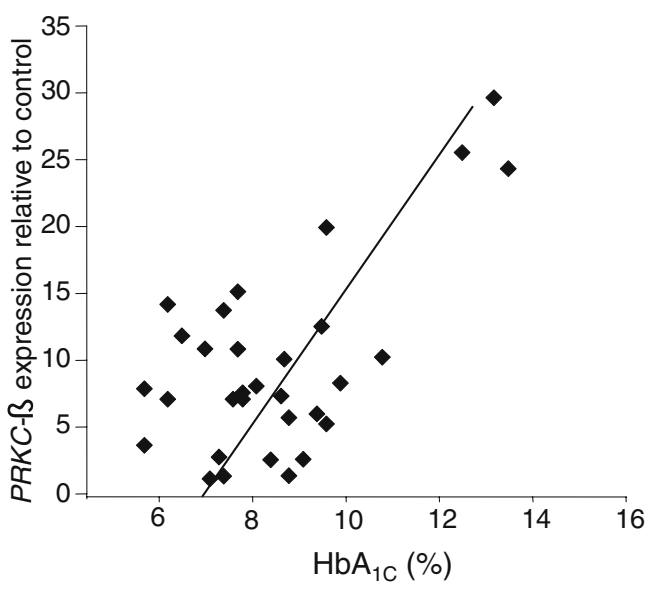

Fig. 3 Graphical representation of the relationship between $P R K C-\beta$ renal gene expression and $\mathrm{HbA}_{1 \mathrm{c}}$ at the time of biopsy, demonstrating a close correlation $(r=0.63, p<0.05)$ 


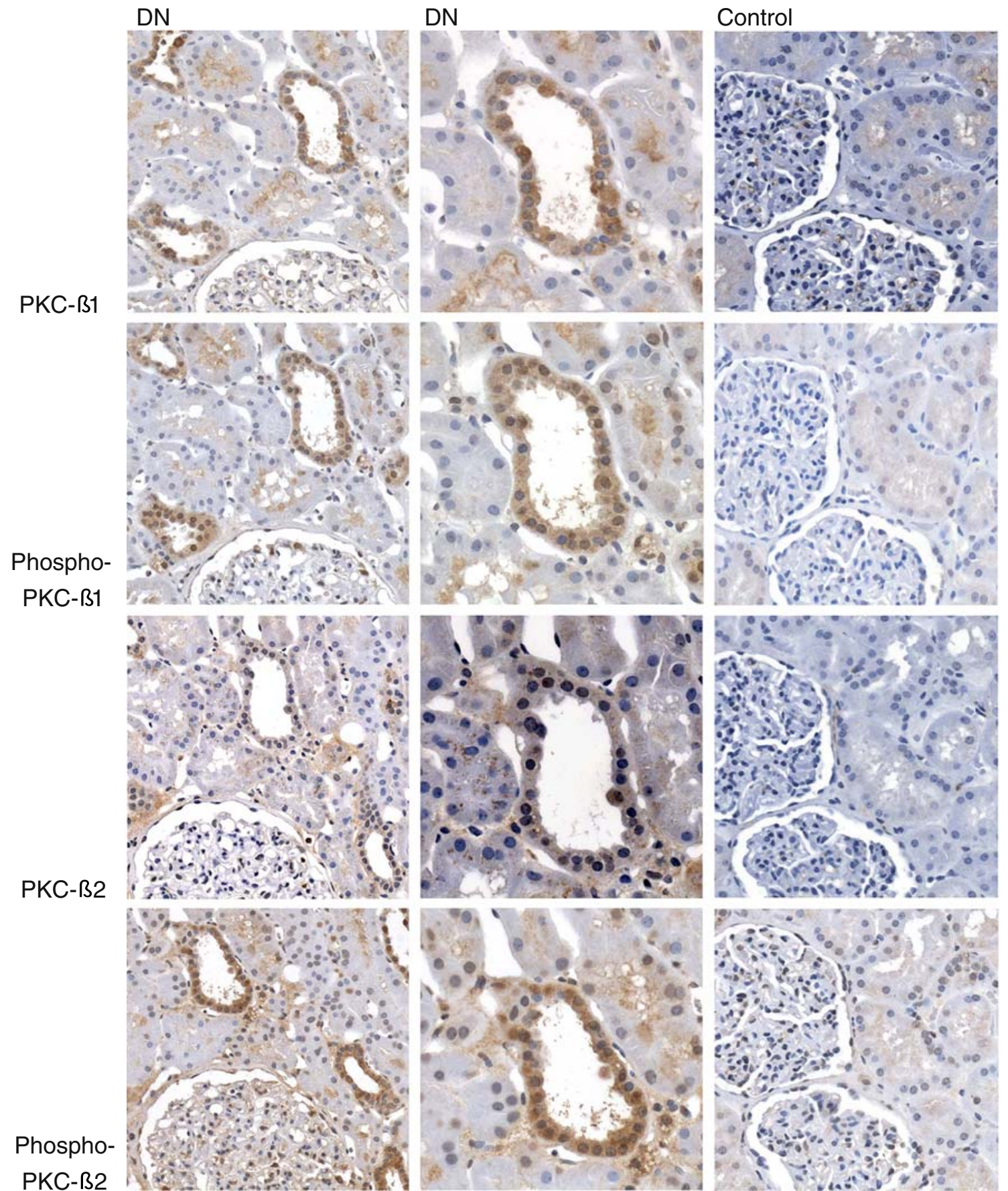

Fig. 4 Representative photomicrograph demonstrating co-localisation of $\mathrm{PKC}-\beta 1, \mathrm{PKC}-\beta 2$, and phospho-PKC- $\beta 1$ and $-\beta 2$ in matched serial sections of human diabetic nephropathy (DN). Staining of both peptide and phosphorylated moiety (brown) was increased compared with control and was seen predominantly in tubulo-epithelial cells Magnification: $\times 160$ (left) $\times 320$ (centre) $\times 160$ (right) prior to acid-phenol-chloroform extraction and carrier precipitation [24]. Although such extraction methods provide good yields, RNA from formalin-fixed tissue is still fragmented. This previously insurmountable problem is now easily overcome using real-time PCR which allows for high-fidelity amplification of RNA fragment lengths of 50 to $150 \mathrm{bp}$. Furthermore, since the RNA degradation that occurs in formalin-fixed tissue is universal, housekeeping RNAs will be equally affected and remain suitable for use in quantitative analyses [24].

Although molecular analyses of archival tissues are now commonplace in the oncology literature, their use in nephrological studies has been less extensive, despite the frequency of kidney biopsies. The present report indicates 
that archival, formalin-fixed, paraffin-embedded human kidney tissue provides a valuable resource.

In summary, the present study demonstrates that $P R K C-\beta$ mRNA is upregulated by high glucose in tubular epithelial cells and in advanced diabetic nephropathy. The mechanisms underlying this upregulation in $P R K C-\beta$ expression and the temporal changes in its distribution in the nephron are uncertain, but underscore the need not only for further exploration of the regulatory elements of $P R K C-\beta$ transcription, but also for prospective, longitudinal analyses of both gene and protein expression in human kidney tissue.

Acknowledgements This study was supported, in part, by an operating grant from the Kidney Foundation of Canada.

Duality of interest The authors declare that there is no duality of interest associated with this manuscript.

\section{References}

1. Ritz E, Rychlik I, Locatelli F, Halimi S (1999) End-stage renal failure in type 2 diabetes: a medical catastrophe of worldwide dimensions. Am J Kidney Dis 34:795-808

2. Krolewski AS, Laffel LM, Krolewski M, Quinn M, Warram JH (1995) Glycosylated hemoglobin and the risk of microalbuminuria in patients with insulin-dependent diabetes mellitus. N Engl J Med 332:1251-1255

3. Gilbert RE, Tsalamandris C, Bach LA et al (1993) Long-term glycemic control and the rate of progression of early diabetic kidney disease. Kidney Int 44:855-859

4. Brownlee M (2001) Biochemistry and molecular cell biology of diabetic complications. Nature 414:813-820

5. Koya D, King GL (1998) Protein kinase C activation and the development of diabetic complications. Diabetes 47:859-866

6. Ishii H, Jirousek MR, Koya D et al (1996) Amelioration of vascular dysfunctions in diabetic rats by an oral PKC beta inhibitor. Science 272:728-731

7. Tuttle KR, Anderson PW (2003) A novel potential therapy for diabetic nephropathy and vascular complications: protein kinase $\mathrm{C}$ beta inhibition. Am J Kidney Dis 42:456-465

8. Kang N, Alexander G, Park JK et al (1999) Differential expression of $\mathrm{PKC}$-isoforms in streptozotocin-induced diabetic rats. Kidney Int 56:1737-1750

9. Meier M, Park JK, Overheu D et al (2007) Deletion of protein kinase $C-\beta$ isoform in vivo reduces renal hypertrophy but not albuminuria in the streptozocin-induced diabetic mouse model. Diabetes 56:346-354
10. Newton AC (1995) Protein kinase C: structure, function, and regulation. J Biol Chem 270:28495-28498

11. Whiteside CI, Dlugosz JA (2002) Mesangial cell protein kinase C isozyme activation in the diabetic milieu. Am J Physiol Renal Physiol 282:F975-F980

12. Kapor-Drezgic J, Zhou X, Babazono T, Dlugosz JA, Hohman T, Whiteside C (1999) Effect of high glucose on mesangial cell protein kinase C-delta and -epsilon is polyol pathway-dependent. J Am Soc Nephrol 10:1193-1203

13. Dlugosz JA, Munk S, Ispanovic E, Goldberg HJ, Whiteside CI (2002) Mesangial cell filamentous actin disassembly and hypocontractility in high glucose are mediated by PKC-zeta. Am J Physiol Renal Physiol 282:F151-F163

14. Kelly DJ, Zhang Y, Hepper C et al (2003) Protein kinase C $\beta$ inhibition attenuates the progression of experimental diabetic nephropathy in the presence of continued hypertension. Diabetes 52:512-518

15. Toyoda M, Suzuki D, Honma M et al (2004) High expression of PKC-MAPK pathway mRNAs correlates with glomerular lesions in human diabetic nephropathy. Kidney Int 66:1107-1114

16. Gilbert RE, Cooper ME (1999) The tubulointerstitium in progressive diabetic kidney disease: more than an aftermath of glomerular injury? Kidney Int 56:1627-1637

17. Johnson DW, Saunders HJ, Brew BK et al (1997) Human renal fibroblasts modulate proximal tubule cell growth and transport via the IGF-I axis. Kidney Int 52:1486-1496

18. Christensen PK, Larsen S, Horn T, Olsen S, Parving HH (2001) Renal function and structure in albuminuric type 2 diabetic patients without retinopathy. Nephrol Dial Transplant 16:2337-2347

19. Stein-Oakley AN, Maguire JA, Dowling J, Perry G, Thomsom NM (1997) Altered expression of fibrogenic growth factors in IgA nephropathy and focal and segmental glomerulosclerosis. Kidney Int 51:195-204

20. Liu Y, Su W, Thompson EA, Leitges M, Murray NR, Fields AP (2004) Protein kinase CbetaII regulates its own expression in rat intestinal epithelial cells and the colonic epithelium in vivo. J Biol Chem 279:45556-45563

21. Fioretto P, Steffes MW, Sutherland DER, Goetz FC, Mauer M (1998) Reversal of lesions of diabetic nephropathy after pancreas transplantation. N Engl J Med 339:69-75

22. Langham RG, Gow RE, Kelly DJ et al (2006) Progressive decline of renal function in $\operatorname{IgA}$ nephropathy is associated with elevated gene expression of PKC- $\beta$. Proceedings of the American Society of Nephrology, Annual Scientific Meeting, San Diego 2006 SA-PO733 (abstract)

23. Masuda N, Ohnishi T, Kawamoto S, Monden M, Okubo K (1999) Analysis of chemical modification of RNA from formalin-fixed samples and optimization of molecular biology applications for such samples. Nucleic Acids Res 27:4436-4443

24. Lewis F, Maughan NJ, Smith V, Hillan K, Quirke P (2001) Unlocking the archive-gene expression in paraffin-embedded tissue. J Pathol 195:66-71 